\title{
Critical Dystopia: Local Narrative in the Threshold in Ahmed Khaled Towfik's Utopia
}

https://doi.org/10.33806/ijeas.19.1.10

\author{
Reem Resheq and Ahmad Y. Majdoubeh \\ The University of Jordan, Jordan
}

\begin{abstract}
This study is an exploration of critical dystopia within a postmodern context. Literary and historical viewpoints associate dystopia with the failed utopia of twentiethcentury totalitarianism manifested in regimes of extreme coercion, inequality, and slavery. Raffaella Baccolini and Tom Moylan, of whose perspective this study makes use, theorize that critical dystopia provides a potential for change through rejecting the traditional dystopian ending marked by the subjugation of the individual. Problematizing critical dystopia further, the study proposes that the critical orientation of this sub-genre originates mainly from the "local narrative" of a subject whose agency generates from his position in the "threshold" between those in and under control, combined with the "counter-conducts" he uses to acquire knowledge, memory, and awakened consciousness. As a full agent, the subject resists the "utopian" "metanarrative" of an oppressive system/structure and offers possibilities of meaning in a process of "différance" which entails a potential for change. This proposition is clarified through the close reading of Ahmed Khaled Towfik's Utopia (2011; first published in Arabic in 2008). The novel is discussed as a critical dystopian text in which Gaber, the subject in the "threshold," opposes the totalitarian regime of Utopia in his "local narrative."
\end{abstract}

Keywords: counter-conduct, critical dystopia, local narrative, postmodernity

\section{Introduction}

The second decade of the twenty-first century has witnessed the emergence of individual and collective acts of resistance to despotic regimes that have, for many years, deprived people of their simplest rights: to live decently, freely, and justly (Engler and Engler 2016:5). This study relates to the relationship between power and resistance as dialectical and pertains to the present moment at which flesh and blood subjects roam the streets and strive on behalf of millions of others against tyranny and fake utopian promises. Having found a literary representation of the time in critical dystopia, the study explores this sub-genre of dystopian literature with references to Raffaella Baccolini and Tom Moylan's definition of it. The paper expands their definition by adding a postmodern dimension to it. The suggested postmodern framework is presented with regards to major conceptions of three eminent postmodern theorists, namely Jean-François Lyotard's "local narrative," Jacques Derrida's "différance," and Michel Foucault's "counterconduct." The study's main proposition is illustrated through tackling Egyptian physician and writer Ahmed Khaled Towfik's Utopia and focusing on the "local 
narrative" of Gaber, the subject in the "threshold" between the dominant and the dominated.

Years before putting the term "critical dystopia" to use, Moylan wrote about dystopian texts which offer some utopian potential. Moylan refers to fiction of this kind as "critical utopia" and later describes works classified under it as "progressively inclined texts that refuse to settle for the status quo [and] manage to explore positive utopian possibilities by the way of their negative engagement with their brave new worlds" (1986: 12; 2000: xiii). Soon after, critical utopia has given way to critical dystopia in Moylan's joint scholarly production with Baccolini. Baccolini and Moylan clarify that critical dystopia:

Allow[s] both readers and protagonists of these novels to hope by resisting closure: the ambiguous, open endings of these novels maintain the utopian impulse within the work. In fact, by rejecting the traditional subjugation of the individual at the end of the novel, the critical dystopia opens a space of contestation and opposition for those collective "excentric" subjects whose class, gender, race, sexuality, and other positions are not empowered by hegemonic rule (2013:7, emphasis in original).

In discussing critical dystopia, Baccolini adds two other important features to contestation and resistance: a state of happiness accompanied with openendedness (2013:130). For her, "a sense of regret and of missed opportunity accompanies the awareness and knowledge that the protagonists have attained." Baccolini further maintains that critical dystopia leaves the protagonist facing his willfully made decisions and that "[i]t is in the acceptance of one's responsibility and accountability, often worked through memory and the recovery of the past, that [he] brings the past into a living relationship with the present and may thus begin to lay the foundations for a utopian change" (ibid: 130). This being said, it is clear that critical dystopia shares with utopia the affirmation of human potentialities, the dream of a better state of existence, and the impulse of change characterizing Humanist, Lockean, Rousseauvian, and Kantian thoughts, among others, and celebrated in utopian literature like Plato's The Republic (written around 380 BC), Thomas More's Utopia (1515), Francis Bacon's New Atlantis (1627), and Sarah Scott's Millenium Hall (1762).

Building on Baccolini and Moylan's definition, critical dystopian fiction includes not only utopian but also dystopian features. The "ex-centric[ity]" of the subjects of critical dystopia of which the two critics write (2013: 7) is a feature in common with critical writings in the like of that of Mary Wollstonecraft (1792), Max Horkheimer and Theodor W. Adorno (2002), and Edward Said (1978; 1993), which expose how the self-proclaimed project of the Enlightenment with its emphasis on universal equality creates more subaltern groups through magnifying gender, economic, and cultural differences, respectively. This accusation of deliberate inequality and marginality of certain segments of society due to hierarchical considerations of gender, class, and race, among other matters, is highlighted in dystopian literature which, Erika Gottlieb describes as "look[ing] at totalitarian dictatorship as its prototype [. . .] a society that finds its essence in concentration camps, that is, in disenfranchising and enslaving entire classes of its 
own citizens"(2001:40-1) as in Aphra Behn's Oroonoko, or the Royal Slave (1688) and Suzy McKee Charnas' Walk to the End of the World (1974).

In critical dystopia, characters undergo oppressive living conditions imposed by dictatorial powers. However, what distinguishes this sub-genre is its critical dimension which adds a utopian aspect to it. Reflecting on Baccolini and Moylan's definition mentioned above, it seems that "critical" means contesting with hegemonic powers. In other words, critical dystopia does not focus solely on the measures of subjugation that authorities use in typical dystopian works but also celebrates the subjects' ability to strive for change. As understood in the study, the critical nature of critical dystopia reverberates the spirit of Postmodernity. The "logocentric" (Derrida 1975:3) self-evident meanings of equality, freedom, and welfare enforced by "metanarratives" (Lyotard 1984:xxiv) like Capitalism, Marxism, and Emancipation Enlightenment are criticized and deconstructed through "différance" (Derrida 1975:25). Added to this, the deceptive "utopian" project such meta narratives claim to serve is exposed by individuals in the "threshold" (Turner 1979) in their "counter-conducts" (Foucault 2003:204) registered in "little" or local narratives (Lyotard 1984:60).

\section{Critical dystopia and the postmodern condition}

Baccolini and Moylan's description of critical dystopia as a work of resistance to marginality and subjugation draws a parallel between this sub-genre and Lyotard's notion of local narrative. Lyotard sees that the postmodern age marks a noticeable change in the condition of knowledge. As a result of the Second World War and the subsequent Cold War strategy of Mutual Assured Destruction (MAD) which shattered the promises of the Enlightenment and modernity, it became clear that scientific knowledge could not be all-inclusive(1984:xxiv). Relevant to this, he argues that metanarratives or "discourse[s] of legitimation [. . .] discourse[s] called philosophy" like Enlightenment Emancipation and Marxism, which legitimated and disseminated the scientific knowledge throughout the west, have been "in crisis and decline"(ibid:60). Lyotard justifies this by arguing that legitimation cannot be but plural, local, and immanent, expressing that in the postmodern age, the discourse of metanarratives is confronted by "networks of uncertain and ephemeral narratives [that] can eat away at the grand, instituted narrative apparatus" (Lyotard qtd in Carroll 1987:76). Though he does not delve deeply into local narratives, Lyotard lists some of those involved in their "lateral skirmishes": "pro-abortionists, prisoners, draftees, prostitutes, students, and peasants ..." (ibid: 76). Building on these entries, many critics have seen stories of resistance in those local narratives. For example, Richard J. Evans argues that those narratives are "forms of resistance, individual stories told by prisoners, students, peasants and deviants of various kinds, impossible to incorporate into the state's version of events, and thus directly subversive of it" (2000:128).Local narratives, in this sense, are polyvocal stories that pertain to little, everyday life experiences which disrupt pre-existing metanarratives of various kinds and their strategies of legitimation. Used to deconstruct totalitarian metanarratives and the 
univocal system of thought they implement, local narratives become "the quintessential form of imaginative invention" which depends on dissention rather than consensus and enables the peripheral to counteract and possibly dismantle the center (Lyotard 1984:60). Hence, local narratives verbalize "différance."

For Lyotard, the dissention is that of meaning and interpretation, for while the metanarrative creates specific and fixed meanings of truth, justice, and progress, reinforced by a dominating discourse, the local narrative challenges those determined meanings and advocates different interpretations of signifiers. Very relevantly, Derrida argues for the way language creates semantic difference and keeps postponing meanings against "logocentrism." Derrida defines "différance" as "[t]he movement by which language, or any code, any system of reference in general, becomes 'historically' constituted as a fabric of differences"(1973:141). In Of Grammatology, he deconstructs the structuralist notion of "logocentrism" which he uses to describe Western thought from the time of Plato through Hegel, in which all forms of thinking were based on an authorizing Logos or center (1975:8). Starting with the favoring of the linguistic "presence" of speech over the "absence" of writing, the bias, Derrida and F.C.T. Moore believe, is carried over from linguistic to social structures grounded by metaphysics including meanings given to concepts like equality, progress, democracy, and welfare in relation to gender, race, seniority, and class, among other matters(1974:68). Derrida refuses "logocentrism" on the basis that language is characterized by "différance," that is, it includes contradictory and irreconcilable structures that render its meanings unfixed and continuously deferred. Derrida's "différance" extends beyond the realm of language to cover every mental or phenomenal event; it explores, undoes, and displaces the rigid conceptual oppositions imposed by different regimes (masculine/feminine, senior/junior, rich/poor, white/non-white, etc) to show that those oppositions are mere constructions and that neither term within the binary system of thought which characterizes logocentrism is primary.

Local narratives, in this regard, offer a space of différance: a vast array of possibilities and potentials for multiplicity, diversity, and equality, opposite to the exclusionary discourse(s) of logocentrism which tailors different metanarratives to serve the interests of one group behind the charade of utopian promises. In the "present" and "official" metanarratives of those in control, the marginalized are undermined as "absent" and "unauthorized"(Derrida and Moore 1974:68). But in their local narratives, the peripheral have the potential to destabilize those metanarratives and the discourses they spread. Challenging the structure takes place through revealing that within the dominant system of thought there exist contradictions regarding its totalizing explanations of life and its phenomena. Attempts to displace a system of thought, here logocentric metanarratives, takes different forms or "counter-conducts," to use Foucault's terminology (2007:204).

Years after expressing that power "makes itself everywhere present" (1995:205), Foucault has written about the likelihood of resistance and the continuity of power struggle: "as soon as there is a power relation, there is a possibility of resistance. We can never be ensnared by power: we can always 
modify its grip in determinate conditions and according to a precise strategy"(1990:123).The emphasis on the ability to resist power brings a new dimension to Foucault's expression that power is everywhere, for not only is it bio-politically fragmented but also shared. Earlier in his intellectual life, Foucault strongly believes that modernity is marked by dispersed networks or apparatuses of power to which he refers as "technologies of power" and "technologies of the self" operating on micro levels as mechanisms of regulatory control and saturation of power in the spaces of everyday life (1988: 18).Writing of the first type, Foucault explains those technologies by arguing that they are "a thoroughly heterogeneous ensemble consisting of discourses, institutions, architectural forms, regulatory decisions, laws, administrative measures, scientific statements, philosophical, moral and philanthropic propositions - in short, the much said as much as the unsaid" (1980:194). As for "technologies of the self," he defines them as "permit[ting] individuals to effect by their own means or with the help of others a certain number of operations on their own bodies and souls, thoughts, conduct and way of being, so as to transform themselves in order to attain a certain state of happiness, purity, wisdom, perfection or immortality"(1988:18).

This Foucauldian understanding of subjectivity is later transformed; Foucault comes to believe that since power is everywhere, it is not restricted to those in authority but is dispersed everywhere and so, it also lies in the hands of the individual, who has the agency to re-construct himself against the power of the State. Foucault clarifies that this new dimension of subjectivity is acquired through "counter-conducts" or "localized practices" that challenge decentered power as in "the refusal to pay taxes and rents or to comply with conscription; the violent confiscation of hoarded goods" (1995:273). Foucault links "counterconduct" to history, memory, and discourse too. For instance, he writes that "counter-history" does not only "break up the unity of the sovereign law that imposes obligations; [but] also breaks the continuity of glory, into the bargain" and "speak[s] from the side that is in darkness, from within the shadows" (2003:70).Likewise, Foucault states that "counter-memory" reveals how power "is fixed, through its history, in rituals, in meticulous procedures that impose rights and obligations" (1977:150).Foucault argues that "counter-history" and "countermemory" apply to the "subjugated knowledges" of discourses that are deemed marginal (1981:81). Those "subjugated knowledges" of the marginalized give room for alternative readings of historical experiences through presenting "counter-discourses" that criticize the centralized ideological matrix. Foucault formulates "counter-discourse" or "reverse discourse" in reference to different groups of marginals in his opus: the discourse of prisoners and homosexuals, respectively (1977:209; 1978:101). "Counter-discourses," in this sense, resist the official discourse and attempt to deconstruct it by giving room to différance. Accordingly, it is here perceived that "counter-conducts" the marginalized or subjugated employ overlap with Lyotard's "lateral skirmishes" and are encompassed in his "local narrative." 
Foucault's "counter-conducts" and Lyotard's "lateral skirmishes" are not far from the "anti-structural" acts which anthropologist Victor Turner discusses in his Threshold theory. As mentioned earlier, those "counter-conducts" and "lateral skirmishes" are practiced by marginalized people or ones who stand outside the established structure of thought. Turner specifies some of those individuals as liminals in the "threshold," that is, between two spaces (1974:233). He writes about liminal individuals of three types: ritual liminals, outsiders, and marginals. Turner argues that people in the threshold "are neither here nor there; they are betwixt and between the positions assigned and arrayed by law, custom, convention, and ceremonial" (2008:95). What renders those individuals antistructural is that the social counter-position ascribed to them becomes a positive force; it allows them to reconsider central values of their culture and surrounding circumstances. Turner mentions that "anti-structure" is not only a stage of reflection but is also a "realm of pure possibility" in which new ideas and concepts, not to forget actions, are stimulated and generated (1979:236). Permitting people to have a clear view on the structure from which they are excluded, being in the threshold represents a danger to those with authority.

When looked at together, "local narrative," "différance," "counter-conduct," and being in the "threshold" embody the ideologically oppositional nature of critical dystopia and help explain its "critical" spirit. Critical dystopia celebrates the ability of "ex-centric" subjects to visualize an alternative utopian horizon or space, and their strife to make it materialize. As understood in the study, the critical nature of this sub-genre of dystopian literature reverberates the spirit of Postmodernity. This assumption is based on the way totalitarian metanarratives like Capitalism, handled in Utopia by Ahmed Khaled Towfik (1962-2018), the univocal, logocentric meanings of equality, freedom, and welfare this metanarrative imposes, and the consequent hierarchical dichotomy it establishes are criticized, confronted, and subverted through Gaber's quotidian, ephemeral activities and everyday counter-conducts registered in his local narrative as an individual in the threshold.

\section{The postmodern condition of Egypt}

A first reading of Utopia might show an exaggerated, even unrealistic, portrayal of Egypt as a compartmentalized world of Utopia's gated enclaves and the shantytowns of the central Cairo district of Shubra. However, the 2020-Egyptian society Towfik depicts comes as a natural extension of the socio-economic conditions Egypt experienced at the time the text was written.

To zero in on the conditions of Egypt under the rule of the National Democratic Party (1981-2011), the government's declared agenda was based on two key words: nationalism and democracy. The cabinet promoted its romanticized metanarrative of Emancipation (later it became clear that it was a metanarrative of Capitalism) in the form of a project that secures equality and the commonwealth of all Egyptians. To encourage progress and modernization, the International Monetary Fund (IMF) recommended neoliberal economic policies to adjust the Egyptian economy in the name of macro-economic stability, and so, 
governmental policies were issued, including reform measures like free market economy and privatization. In spite of these measures, the NDP's project was deceptively utilitarian. Alleged vote-rigging in parliamentary elections led to the unprecedented success of the ruling party and a businessmen-dominated government was ensured. Emad El-Din Shahin writes that internal dynamics of cronyism and profiteering enabled businessmen to "accumulate wealth through the privatization of state-owned enterprises, real estate, doubtful business dealings, and financial breaks"(2012:51).The spoken of economic growth excluded the middle and working classes, and monopoly increased the already high rates of unemployment. Not only this, but it is reported that the government also withdrew from providing essential public services like good education and healthcare, and failed to stop high birth rates (Elie Podeh mentions 1.6 million newborns recorded annually (2012:12). As a result of the rampant economic corruption and social injustice, the Egyptian social fabric was destroyed and an uneven social structure materialized in the stark disparity between what came to be known as the gated communities of the elite and the slums of the impoverished. In this context, Shahin cites a 2007 study conducted by the Cabinet's Information and Decision-making Support Centre and other government sponsored institutes. The study shows that more than 17.7 million people lived in slums spread among twenty Egyptian governorates (2012:51).Meanwhile, Islam Ghonimi, Hassan El Zamly, Mohamed Khairy and Mohamed Soliman document more than 450 gated communities until 2010 located in Greater Cairo Region (2011:1351). This reality was noticed by many thinkers and writers, one of whom is Towfik, who portrays it in the dichotomous world of Utopia/Shubra.

\subsubsection{Ahmed Khaled Towfik's Utopia}

Depending on the satirical technique of externalizing events, Towfik starts his work with a disclaimer in which he emphasizes that "[a]ny resemblance to places and individuals in our present reality is purely coincidental"(i). But behind this attempt of fictional distancing lays what is here assumed to be an intended likeness. Most, if not all, of the events of Utopia point to the economic and social "achievements" of the NDP's capitalist metanarrative during the first ten years of the new millennium. More than that, the narrative describes the postmodern condition ensued under the impact of "late capitalism."Frederic Jamesonposits that "late capitalism" is a new multinational, consumerist phase of capitalism relating to a globalized, post-industrial economy that contributed in the emergence of the postmodern condition marked by commodification and consumability, and international capital markets (1991: 36).

In Utopia, the postmodern condition appears vehemently in the lifestyle of those who reside in Utopia. Narrating three parts of the novel, Alaa', a young adult dweller of Utopia, leads a life of endless consumption. Describing his killing routine, he expresses: "I wake up. I take a leak. Smoke a cigarette. Drink coffee. Shave. Fix the wound on my forehead to make it look terrible. [. . .] In an hour, I've done everything, and there's nothing left in life that interests me or that I 
want!" (16-7). Like in the case of his peers, Alaa's emotional numbness and isolation are sensed in those words. Also important is how the quotation reveals the meaningless life he leads and his need to experience something more daring. Having consumed all that could be preyed on in the "artificial paradise" of Utopia (9), he decides to set out on an escapade to collect some human souvenirs. Convinced that human objectification is not less ordinary from object commodification, he, together with his friend Germinal, leaves the fortified compounds of Utopia for Shubra to "hunt" one of the "Others" for sport (12).

Another feature of the postmodern condition of Utopia appears in the reform measures, like free market economy, which open the door for globalization. This aspect of life carries a strong sense of contradiction regarding the meaning of plurality since out of their logocentric mentality, Utopia's tycoons restrict plurality and, consequently, equality, to international investors and foreign residents. Ironically, Alaa' narrates that his community is a miniature of a global city that welcomes diversity; not only Egyptians (undoubtedly the well-off) but also people of other nationalities (he names Americans and Israelis) live, and international capitals and economic investments operate. This biased understanding of plurality leaves all the structures of power and inequality intact, symbolized in a firmly-erected social hierarchy that divides Egypt into gated compounds and slums. The metanarrative of capitalism makes of richness and poverty two well-deserved conditions in Utopia and the shantytowns, respectively, for both the wealthy and the needy are given equal chances to prosper, but only the moguls understand the rules of the game and benefit. Put in the words of Alaa', "[w]hile our fathers were taking advantage of opportunities, your fathers were queuing to get their salaries from government agencies. Then there were no more government agencies. There were no more salaries" (132).

Faisal Darraj suggests another dimension of equality in Utopia. In "Yūtūbiyā Ahmed Khaled Tawfik wal al-Arwah al-Mayyita" he maintains that the utopian dream is achieved through the existence of two cities with two different forms of equality: equality of richness in Utopia and of poverty in Shubra (2009). In Utopia, "the community has carved its own separate laws and courts" (14). There, disorderly conduct like breaking into the personal property of another Utopian is punished. Outside this "utopian" world, a different kind of equality exists. In the slums, all rights are violated and crimes like rape and theft are permitted and self-avenged. Darraj's opinion proves right when read in light of Towfik's reference to the medieval version of equality established among equals within a given social class. This logocentric definition of equality is manifested in the novelist's allusion to Edgar Allen Poe's short story "The Masque of the Red Death" set in the Middle Ages, during which the concept of gated communities was prevalent. In the short story, Prospero, a dispassionate prince, walls himself and other wealthy nobility in his gated castle against the deadly plague, seeing that "the external world could take care of itself" (1965:42). Adopting the same medieval mentality, Utopia's rich erect an inviolable architectural structure of gated compounds as a "technology of power" to guarantee their own safety 
through disciplining the poor and ensuring the demographic control of social classes.

In addition to spatial separation, the regime sustains power dynamics through controlling slum dwellers biologically. To decrease the population rate in Shubra and similar areas, the government resorts to other "technologies of power": castration and food contamination. More dangerous is the government's tolerance of drugs, especially "Phlogistine" and "Libidafro," which are easily acquired in Utopia and are smuggled to Shubra (7). Harry Morgan describes these two types of drugs as "pharmakon," a term he borrows from Derrida's coined combination of Plato's Phaedrus which means "the drug: the medicine and/or poison"(2017).Morgan sees that "acquiring and consuming drugs is viewed as the raison d'être for both Utopians and Others, providing them with the only avenue they have to even "pretend to be human"" (2017)."Phlogistine" and "Libidafro", not to forget glue sniffing, operate as a "technology of the self" for the people of Shubra, who take them for the sake of detaching themselves from the horrendous life they lead. Somehow a tool of self-regulation, those drugs damage people's mind cells on the long run and control, if not destroy, their consciousness.

In Utopia, "technologies of power" extend to the media in a way that brings to mind George Orwell's Nineteen Eighty-Four. In Orwell's novel, media function as channels through which INGSOC Party diverts the attention of the public, desensitizes it, and normalizes the status quo in Oceania. There, cheap "books, periodicals, pamphlets, posters, leaflets, films" serve the slogan "IGNORANCE IS STRENGTH" (1989:42, capitalization original). In the same vein, the newspapers distributed in Shubra are a "strange mix of sex, religion, fairy tales and conspiracy theories. The front page is full of the phrases 'Revealing the Hidden', 'Behind Closed Doors', 'Magic' and 'Rape', etc., with a general insinuation that all women are whores and all men are pimps" (98).

The effect of the systematic disciplinary practices of the Utopiandominated government on Shubra is apparent in the way they propel its inhabitants to believe the essentialist discourse of the Utopians. The poor come to see that they are the "Others" (12). People like Bayoumi, Mitwalli, and Azza do not mind being humiliated to the degree of actually eating dogs. Yielding to the propagated claims of the supremacy of the rich, they accept as true that the rift between the two parties could never be bridged, and so, statements like Alaa's "You didn't catch on the game early on, so you fell from high up into a bottomless pit" (132) are deeply ingrained in their minds that self-victimization becomes the norm and rebellion a matter of no concern to them.

\subsubsection{Gaber's local narrative: the "dream of something beyond"}

Beside Alaa', the teenager who speaks for the rich and their capitalist metanarrative, Towfik chooses Gaber to be the second narrator of Utopia. In its essence, Gaber's local narrative is the story of an intellectual shantytown denizen from Shubra who problematizes and attempts to deconstruct the coercively 
structured life mandated by the ruling system through the ephemeral activities he engages himself with, namely those of critically reading about the reasons behind the unjust reality postmodern Egypt lives and observing those reasons in his locale. Bringing to mind Foucault's "counter-memory" and "counter-history," Gaber's readings and personal reflections give him the ability to invent a "counter-discourse" through which he, and in effect, his locals "speak [their] truth back to power" (Said 1994:xvi). Using his voice, Gaber makes of speaking the "counter-conduct" through which his local narrative responds to Utopia's metanarrative and its logocentric discourse.

Simple though it seems, Gaber's constant emphasis on his "dream of something beyond sex" carries in its folds a much deeper meaning (47). In Shubra, sex is an encompassing term for poverty, violence, and ignorance to which the paupers of Egypt surrender. Gaber, however, opposes the mainstream by resisting injustice and dreaming of a more decent life. His resistance is translated into a personal decision to nurture his mind through choosing some reading material of a completely different nature from that of other slum dwellers. Instead of magazines full of scandals and conspiracy theories, he "sifts through the rubbish for every old book he can find" (85). Gaber chooses to read a variety of works, including "the theories of Malthus and Gamal Hamdan and the prophecies of Orwell and H. G. Wells" (63).

Gaber's choice of readings deserves consideration. To begin with, Thomas Robert Malthus summarizes his theory of Population Growth as he states that" [p]opulation, when unchecked increases in geometrical ratio. Subsistence increases only in an arithmetical ratio" (1966:14). By this, Malthus seems to mean that population will inevitably increase considerably based on geometrical or numerical progression and that food production will not be able to keep pace with this acceleration in population ratio. Building on this scenario, Malthus warns against a chaotic future reality in which the world is to suffer from starvation. As for Egyptian geographer Gamal Hamdan, one of his most notorious hypotheses that pertain to Utopia is expressed in Shakhsiyat Misr: Dirasah fi Abqariyat Almakan. In his book, Hamdan argues that authoritarianism is a fundamental trait of the Egyptian government stretching back to antiquity. Still, Hamdan affirms that being armored with the spirit of justice and resilience, Egyptians have always resisted despotism no matter how long it would last (1967: 585). Gaber's familiarity with George Orwell and H. G. Wells, and their "prophecies" is also quite interesting (63). One of the Orwellian predictions which Gaber might have examined relates to the prospective conditions of humanity in which the future proffers different regimes the ability to subjectify people and manipulate their minds through micro-level practices instead of typical technologies of domination like imprisonment and corporeal torture (Gaber's knowledge of Orwell could be related to the fact that Towfik translated Orwell's novel to Arabic). Possibly also, it could be suggested that Gaber is capable of recognizing the parallel condition between his people, who are victimized by Utopians, and the Eloi, who are preyed on by the Molocks in Wells' The Time Machine, which explains Towfik's use of "predator" and "prey" in Utopia. 
In the course of the novel, Gaber's familiarity with the writings of Malthus, Hamdan, Orwell, and Wells is critical. In the process of reading, he is able to find affinities between what those writings describe or warn about and the present Egyptian condition. Malthus' theory proves valid in the poor districts of Cairo. As Gaber contends, the poor do not think of solutions to help alleviate their hunger but rather continue to multiply, believing that "one of their sons will change everything. While waiting for this unknown, they multiply, and the boy scratches around for his daily bread, like a chicken" (90). Hamdan's account on the totalitarian nature of the Egyptian government is best sensed in Egypt's 2020 government in which all power is concentrated in the hands of a few businessmen. By the same token, Shubra is not far from the Orwellian vision of disindividualized power and domination of humans, and the Wellsian prophecy of the danger of uncontrollable scientific advancements.

Reading stimulates Gaber to critically reflect on past conditions which his people have lost memory of. It gives Gaber the chance to see that "there had been some terrifying indicators, and everyone should have taken notice of them" (109). In his daily observations in the poor districts of Shubra, he thinks of how things "grew worse without an abrupt change. Each time, the difference between yesterday's situation and today's was slight, so a person closes his eyes every night muttering to himself: 'That's life. Life is still possible. You are still capable of finding food, shelter, and some treatment. So let tomorrow come" (47). Gaber remembers small details that no longer exist in Shubra. He recalls Shubra Street, a main wide street that has been turned into an area full of ancient, crowded hovels. $\mathrm{He}$ recalls that a cinema was there too, once, that mobile phones and communication networks existed but disappeared when "Mansour bey, the telecoms king, took them over" (60, emphasis in original). Recounting the past, Gaber acknowledges how the people of Shubra have been further contained when the government gave up on public transportation services and the underground with its "broken-down subway carriages like lifeless beasts" became a hotbed for thugs and hashish dealers (48).

The keen intellect gained from reading and the observations it helps generate position Gaber in the "threshold" or somewhere "betwixt and between" the space of the dominant structure of Utopia dwellers and the other of the subjugated poor of Egypt, to use Turner's expression (1979:234). Read in light of Turner's theory, Gaber is consigned as the "outsider," whom Turner defines as someone "set outside the structural arrangements of a given social system [...] or voluntarily setting himself apart from the behaviour of status-occupying, roleplaying members of that system"(1974:233).This outsiderhood originates from Gaber's self-willed decision to behave as differently as possible from his own locals. Reflecting on his "threshold" position, he expresses "[. . .] I ended up not belonging to the Others and not belonging to Utopia. In every situation, I am strange, different, peculiar, foolish, uncomfortable and unintegrated" (109). Yet, being an outsider does not drive Gaber to give up on his people. Contrary to that, Gaber strives to include an entire slice of society in his mental resistance through 
the "anti-structural" counter-conduct of speaking to his people, in hope to raise their awareness toward the injustice practiced on them and to the fact that they have willingly conspired against themselves. To achieve this, he chooses to enlighten his peers by using their local discourse. Representing the nexus of his moral responsibility toward other slum dwellers, the following statement by Gaber deserves quoting at length:

There was someone who gathered the good-for-nothings, the sluggish, the bums, and those lacking ambition from the ends of the earth into one national homeland - Egypt. That's why you don't find people lacking ambition in Japan. That's why you don't find good-for-nothings in Germany. That's why you don't find bums in Argentina. They're all here, my friend [...] Those people are you, you dogs! [ . . . Your situation has sunk so low that you're now eating dogs! I warned you a thousand times! I told you about the theories of Malthus and Gamal Hamdan and the prophecies of Orwell and H. G. Wells. But all you do is get high on hashish and cheap liquor and pass out. Now I swing between sadness over your condition, which is my condition as well, and curses, because only now do you realize (62-3, emphasis in original).

Despite the cynical tone they hold, Gaber's words are imbued with genuine grief over his wretched people. Of equal significance is his admitting that he and the masses are in the same boat (Gaber is honest enough to acknowledge that he is also socially constructed as he joins thugs and sells drugs). Still, Gaber chooses to swim against the tide and is determined to re-construct himself and to author his own life as a free-willed subject whose spirit dissents and opposes rather than accommodates with the unjust present conditions.

Gaber's intensive reading proves equally important in the way it contributes to his resistance which exceeds the boundaries of his local front and reaches Utopia, manifested in the most crucial part of his local narrative when he encounters Alaa' and Germinalas they sneak into Shubra for human hunt (the fact that danger and violence represent a basic element of Shubra's life conditions makes of such an encounter an ordinary event in Gaber's habitat and so, in his local narrative). With antagonism being the name of the game among Egypt's rich and poor, it might be quite natural, and possibly legitimate, for the oppressed to kill their victimizer before being killed. As the plot moves, Gaber is offered many chances to avenge himself and his people by "humiliating a class as a whole. Humiliating circumstances" (116). At a certain point, he has the opportunity to sexually assault Germinal and to force her on to the streets. Opposite to what is expected, however, Gaber settles on keeping Alaa' and Germinal out of the reach of the thugs and decides to secretly transport them back to Utopia. Affirming his agency and self-authorship, he expresses that rescuing the two is "the sole proof I have that I am still human, and haven't turned into a hyena" (104). Gaber adds "I don't want bloodshed. I don't want people killed," anticipating, nevertheless, his own death (104).

Indeed, Gaber does put his life at stake and ends up paying the highest of prices to his predators yet not before threatening their very existence. His threat of 
the regime, represented in Alaa' and Germinal, and the capitalist metanarrative it adopts, takes many forms, starting with the counter-discourse he confronts them with. Not sufficing for reading, he uses his voice as a "counter-conduct" to speak, especially of history. Gaber's entry into the Lacanian realm of the Symbolic through language and his use of his voice enable him to find a subject position within the logocentric system of prey/predator and rich/poor, and to assert his self-authorship through engaging with Alaa' in a heated dialogue of two equally valid voices. To achieve this, Gaber allows an interplay between the present, controlled by the magnates of Egypt, and the long-forgotten past they manipulated to shape this present. Gaber shakes the regime's metanarrative of capitalism and its utopian impulse of equality when he introduces his own "language game" (Lyotard 1984:xxiv) against that of the Utopians and faces them with a different "truth." Getting to know that Alaa', a good reader of philosophy, religion, and literature but not of history and politics, cares only about "what we are now and what we will be," (22) Gaber, his intellectual equal, expresses: "Of course you don't understand a thing about the situation we've got into. But I'd hate not to tell you everything" (81). Recalling central historical accounts, he negotiates with the two intruders over the way the wealthy families of Utopia have taken advantage of the majority of Egyptians, and have come to rule the country. He points out that the social gap between the rich and the poor has always been a reality but that the great collapse took place in the first decade of the twenty-first century with the break of the dam, the failure of tourism, Israel's opening its own canal to substitute the Suez Canal, the appearance of biroil, which replaced Gulf oil, and, above all, privatization which aggravated the conditions of the middle and lower classes: "Everything played into the hands of your fathers and against us, all down the line. So your class was able to stick together, and its wealth expanded, while we fell into the abyss [...] And now two societies have formed: one of them owns everything and the other owns nothing" (82).

In his confrontation with Alaa' and Germinal, Gaber changes power dynamics as he introduces them to the real world of Shubra. Setting out to show them into the Others' society, he makes the two intruders listen to the untold side of the regime's metanarrative and its utopian venture. More pivotal is that by making the two experience the life of the impoverished, Gaber disrupts the "logocentric" meaning of equality by introducing a new signification to it, proving that when put in the ruthless conditions of the slum dwellers, the rich would end up behaving like them. To assert this similarity, Gaber takes the two in "a tour in which he would show [them] a world [they] were completely ignorant about" (89). In the case of Germinal, her real experience in Shubra's neighborhoods brings her closer to vulnerable slum dwellers. In the course of the adventure, she finds herself forced to adapt to their lifestyle as to ensure her own survival. Not only does she adopt their discourse, but she also imitates their behavior; she curses constantly like they do, steals just like them, and automatically "scratch[es] her chest and head, as if the first swarming with fleas and the other with lice" (89). 
Alaa's time in Shubra is not less harsh than Germinal's. Gaber's plan to introduce Alaa' to the real world of the slums materializes when he involves him in his every day activities like chicken de-boning. At the chicken slaughter area where Alaa' is forced to earn his daily bread, he cuts himself so often until he could not distinguish his blood from the chickens'. Witnessing all this, Gaber thinks to himself: "Nothing wrong with that! Some kinds of revenge don't include murder, but in spite of that, they are deliciously pleasant. [. . .] Let him experience it. Let him learn. Let him suffer" (112). On a personal level, Gaber's threat of Alaa' exposes him to a truth he has never known before. For the first time in his life, Alaa' is able to see his world and that of Shubra within the same frame:

I thought of Utopia and my house, and the dollars I fling around. I remembered my group of friends, and the phlogistine I burned with desire for [. . . ] Only then did I understand the reason for those high walls and the Marines and the internal airport. If we abandoned all that, this flood would pour in to drawn us and kill us (92-3).

The feeling of insecurity accompanied by the humiliation that overpowers Alaa' drives him to restore his depleted ego through murdering Gaber, who affirms his own agency by delivering the two to the borders of Utopia "[b]ecause I want to do it," (142) as he explains. In a tunnel through which the three walk, Alaa' does not get enough of killing; he amputates Gaber's arm and keeps it as a human trophy, embalms it, and puts it for display among his friends. Ironically enough, Alaa' does not realize that in maintaining the arm, he keeps Gaber's threat of him present. Truly, Gaber's murder at the hands of Alaa' actualizes his own death anticipation at the end of the adventure. Yet in the embalming of his arm, Gaber is not defeated; it fulfills his promise to disturb the security of Utopians forever as he expresses "One day, I will die, and I'll come to haunt them in the guise of a demon or a ghost, and I'll make their lives hell" (109).

The significance of embalming Gaber's arm has many layers, the clearest of which is Alaa's intention to display it as solid proof of his strength. Possessing the arm also implies Alaa's attempt to win back his masculinity and power that Gaber threatens: "I told our story a million times, and each time I added new details that provoked the imagination. I had become a man. I had gone there and returned, with someone's severed arm" (147). A deeper meaning can be attached to Gaber's arm in light of Derrida's notion of absence and presence. In her introduction to Of Grammatology, Gayatri Chakravorty Spivak restates Derrida's idea, referring to it as the "trace" which is "the mark of the absence of a presence, an always-already absent present" of the "originary lack"(1975:xvii). In Derrida's opinion, the significance of the absence and removal of a sign becomes most clear when it is no longer present. This applies rightly in the case of Gaber's arm which serves to emphasize rather than delimit his influential existence. As a human remain, the arm stays alive, for the word "remain" indicates what continues to exist from the past to the present and the future. More essentially, the souvenir guarantees that Gaber and his narrative remain alive, for the souvenir does not give full meaning except when accompanied by a narrative that identifies its real owner and the way it has come to someone else's possession. Considering Alaa's 
utterance that he has told the story many times, it is quite sarcastic how in his attempt to overpower Gaber and to muffle his voice, Alaa' ends up doing him the biggest of favors, that of fulfilling his promise to haunt Utopians.

Gaber's symbolic death does not only threaten Alaa' but it also shakes the society of Utopia at large. His murder introduces a new dimension to the Egyptian postmodern condition represented in blurring, on many levels, the line which distinguishes the prey/predator dichotomy so the rich and the poor end up being both the prey and the predator. To begin with, Gaber's death takes place while carrying a torch whose light "surround[ed] him like a halo" (143). The last straw, Gaber's death upsets the totalitarian order by inspiring his fellows to re-vision themselves as people of free will and, consequently, to start the long-waited-for revolution, proving the validity of Hamdan's conviction of an inevitable militant confrontation with tyranny. With the news of his murder and mutilation, not to forget Alaa's rape of Safiya, Gaber's sister, spreading throughout his neighborhood, crowds of slum dwellers vow to avenge Gaber on his predators. The throngs invade Utopia through the same tunnel Gaber takes. Holding torches, they affirm that his dream of something beyond has been passed on to them. With the digged tunnel symbolizing a crack in the closely-knit structure of Utopia, the poor demystify the myth of Utopia's fortified gated community. The revolution begins with the masses sabotaging Utopia's means of transport by filling all of its plane tanks with excrement, turning it into a big prison similar to Shubra. Abd elZahir, Mitwalli, el-Sirgani, Safiya, Azza, Mina, Shehata, and thousands of others show Utopians the meaning of segregation they themselves live in shantytowns.

Reading Towfik's Utopia as a critical dystopia, the utopian potential of the text resides in the open-endedness the novel offers within the paradigms of Postmodernity. The novel concludes with the disruption of Utopia's logocentric mindset through "différance." In the act of breaking into the enclaves of Utopia and demolishing the line that sets the two regions apart as two separate worlds, the masses give a new postmodern meaning to space. Elizabeth H. Jones explains this dimension of the postmodern condition when she states that "postmodern space can be characterized as devoid of any over-arching plan or logical order. On the contrary, established categories are increasingly undermined and spatial boundaries eroded" (2007: 51). Jones further adds that "postmodern place, real or fictional, must be more fluid, based on continuous redefinitions, and open to multiple histories and traditions" (ibid: 51). Applying this to Utopia, it is argued that with Shubra and Utopia being connected through the secret tunnel, the welldefined boundaries that separate the two regions deteriorate and the overall Egyptian space becomes a borderless arena with no center and no periphery, one open for different futures and equally valid discourses competing for legitimacy. Rather than one voice that valorizes the metanarrative of the utopians, polyphony of voices is heard in the now borderless space of confrontation of Egypt.

Towfik articulates the dismantling of Utopia/Shubra dichotomy and shows plurivocality that marks the end of Utopia as he deconstructs the structure of the novel in the last two pages. In its entirety, the structure of the novel mirrors the 
strictly separated worlds of Utopia and Shubra as the novel is divided into five rigidly defined parts, three focusing on Alaa's perspective on events and two on Gaber's. However, the last two pages fuse the two perspectives together. Towfik presents this polyphony in his choice to end Utopia by merging lines from the orgasm songs commonly played in Utopia (the lyrics represent the aggressive attitude of authority) with others from "Al-Ahzan Al-Adiyya" composed by Abdel Rahman el-Abnoudi, Egypt's poet of the poor and marginalized, frequently quoted by Gaber:

That's the moment I really love you

Put your neck, my little one

Put your neck on the sacred stone

I shoot

I shoot

Beat the crap out of me and ruin my life

We have seen beyond our differences

Arrest me or let me go and walk all over me

We have seen beyond our differences (156-7).

\section{Conclusion}

Having examined Towfik's Utopia as an example of critical dystopia and Gaber's story as a "local narrative" of resistance, the study has hopefully stretched out Baccolini and Moylan's definition of critical dystopia. Gaber's story demonstrates that in the postmodern age in which plurality cannot be ignored, ruling through totalitarian "metanarratives," "logocentrism," and "technologies of power" and "technologies of the self" is inevitably faced by "local narratives" of resilient subjects who refuse to give in to the fixed meaning of utopia and willfully reconstruct it to proffer possibilities of evolving change and "différance. Standing in the "threshold," Gaber reconstructs himself and opens the door of resistance for the silenced within Utopia in a way similar to Towfik, who opens the door of possibilities for the readers outside the text through choosing an unfolding ending. 
Reem Resheq (PhD)

University of Jordan

11942

Amman-Jordan

Email: reemresheq@gmail.com

Ahmad Y. Majdoubeh $(\mathrm{PhD})$

University of Jordan

11942

Amman-Jordan

Email: amajduba@ju.edu.jo

\section{References}

Baccolini, Raffaella. (2013). 'A useful knowledge of the present is rooted in the past': memory and historical reconciliation in Ursula K. Le Guin's the Telling'. In Raffaella Baccolini and Tom Moylan (eds.), Dark Horizons: Science Fiction and the Dystopian Imagination, 113-134. New York and London: Routledge.

Baccolini, Raffaella and Tom Moylan. (2013). 'Dystopia and histories'. In Raffaella Baccolini and Tom Moylan (eds.), Dark Horizons: Science Fiction and the Dystopian Imagination, 1-12. New York and London: Routledge.

Carroll, David. (1987). 'Narrative, heterogeneity, and the question of the political: Bakhtin and Lyotard'. In Murray Krieger (ed.), The Aims of Representation: Subject, Text, History, 69-106. California: Stanford UP.

Darraj, Faisal. (2009). 'Yūtūbiyā Ahmed Khaled Tawfik wal al-Arwah alMayyita'. $\quad$ http://www.ahewar.org/debat/show.art.asp?aid=177523 (Retrieved on 11 November, 2017).

Derrida, Jacques. (1973). Speech and Phenomena.Trans. David B. Allison. Illinois: Northwestern University Press.

Derrida, Jacques. (1975). Of Grammatology. Trans. Gayatri Chakravorty Spivak. Baltimore: Johns Hopkins Press.

Derrida, Jacques and F. C. T. Moore. (1974). 'White mythology: metaphor in the text of philosophy'. New Literary History, 6: 5-74.

Engler, Mark and Paul Engler. (2016). This is an Uprising: How Nonviolent Revolt is Shaping the Twenty-First Century. London: Hachette UK. 
Evans, Richard J. (2000). In Defence of History. New York and London: W. W. Norton \& Company.

Foucault, Michel. (1977). Language, Counter-memory, Practice: Selected Essays and Interviews. Trans. Donald F. Bouchard and Sherry Simon.New York: Cornell UP.

Foucault, Michel. (1978).The History of Sexuality:The Will to Knowledge.Trans. Robert Hurley. New York: Pantheon Books.

Foucault, Michel. (1980). Power/Knowledge: Selected Interviews and Other Writings 1972-1977. Trans. Colin Gordon, Leo Marshall, John Mepham, and Kate Soper. New York: Pantheon Books.

Foucault, Michel. (1988). 'Technologies of the self'. In Luther H. Martin, Huck Gutman, and Patrick H. Hutton (eds.), Technologies of the Self: A Seminar with Michel Foucault, 16-49. London: Tavistock Publications.

Foucault, Michel. (1990). 'Power and Sex'. In Lawrence D. Kritzman (ed.), Politics, Philosophy, Culture: Interviews and Other Writings, 1977-1984. London: Routledge.

Foucault, Michel. (1995). Discipline and Punish: The Birth of the Prison. Trans. Alan Sheridan. New York: Vintage Books.

Foucault, Michel. (2003). Society Must Be Defended: Lectures at the Collège de France. Trans. David Macey. New York: Picador.

Foucault, Michel. (2007). Security, Territory, Population: Lectures at the Collège de France, 1977-78. Trans. Graham Burchell.New York: Palgrave Macmillan.

Ghonimi, Islam, Hassan El Zamly, Mohamed Khairy, and Mohamed Soliman.(2011). 'The contribution of gated communities to urban development in greater Cairo region, New Towns'. Journal of Al Azhar University Engineering Sector, 21 (6): 1349-1364.

http://www.cpas-

egypt.com/pdf/Islam\%20Ghonimi/ghonimi\%20et\%20al.\%20The\%20contrb ution\%20of\%20gated\%20communities\%20to\%20urban\%20development.p df (Retrieved on 10 November, 2017).

Gottlieb, Erika. (2001).Dystopian Fiction East and West: Universe of Terror and Trial. Montreal and Kingston: McGill-Queen's UP.

Hamdan, Gamal. (1967). Shakhsiyat Misr: Dirasah fi Abqariyat Al-makan. Cairo: Dar Al-Hilal.

Horkheimer, Max and Theodor W. Adorno. (2002). Dialectic of Enlightenment. Trans. Edmund Jephcott. California: Stanford UP. 
Jameson, Frederic. (1991). Postmodernism: Or, the Cultural Logic of Late Capitalism. London and New York: Verso.

Jones, Elizabeth H. (2007). Spaces of Belonging: Home, Culture, and Identity in $20^{\text {th }}$ Century French Anthropology. Amsterdam: Rodopi.

Lyotard, Jean-François. (1984). The Postmodern Condition: A Report on Knowledge. Trans. Geoffrey Bennington and Brian Massumi. Minneapolis: University of Minnesota Press.

Malthus, Thomas Robert. (1966). AnEssay on the Principle of Population. London: Macmillan.

Morgan, Harry. (2017). 'A brave new Cairo? the pharmacology of Ahmed Khaled Towfik's "Utopia"'. https://www.culturised.co.uk/2017/02/a-bravenew-cairo-the-pharmacology-of-ahmed-khaled-towfiks-utopia/(Retrieved on 14 November, 2017).

Moylan, Tom. (1986). Demand the Impossible: Science Fiction and the Utopian Imagination. New York and London: Methuen.

Moylan, Tom. (2000). Scraps of the Untainted Sky: Science Fiction, Utopia, Dystopia. Colorado: Westview Press.

Orwell, George. (1989). Nineteen Eighty-Four. London: Penguin Books.

Podeh, Elie. (2012). 'Farewell to an age of tyranny? Egypt as a model of Arab revolution'. Palestine-Israel Journal of Politics, Economics \& Culture, 18 (1): $10-18$.

Poe, Edgar Allen. (1965). 'The masque of the red death'. In Vincent Price and Chandler Brossard (eds.), 18 Best Stories by Edgar Allan Poe, 41-47. New York: Dell Publishing.

Said, Edward. (1978). Orientalism. New York: Pantheon.

Said, Edward. (1993). Culture and Imperialism. New York: Vintage Books.

Said, Edward. (1994). Representations of the Intellectual: The 1993 Reith Lectures. London: Vintage Books.

Shahin, Emad El-Din. (2012). 'The Egyptian revolution: the power of mass mobilization and the spirit of Tahrir square'. Journal of the Middle East and Africa, 3: 46-69.

Towfik, Ahmed Khaled. (2011). Utopia. Trans. Chip Rosetti. Doha: Bloomsbury Qatar Foundation Publishing.

Turner, Victor W. (1974). Dramas, Fields, and Metaphors: Symbolic Action in Human Society. Ithaca and London: Cornell UP.

Turner, Victor W.(1979). 'Betwixt and between: the liminal period in rites de passage'. In William A. Lessa and Evon Zartman Vogt (eds.), Reader in 
Comparative Religion: An Anthropological Approach, 234-243. New York: Harper and Row.

Turner, Victor W. (2008). The Ritual Process: Structure and Anti-Structure. New Brunswick and London: Aldine Transaction.

Wells, H. G. (2017). The Time Machine. London: Macmillan Collector's Library.

Wollstonecraft, Mary. (1844). A Vindication of the Rights of Woman. London: William Strange. 